\title{
GEOGRAFIA DA MINERAÇÃO DE OURO NO MUNDO DA GLOBALIZAÇÃO FINANCEIRA
}

\author{
Global Gold Mining Industry in the period of financial globalization
}

\author{
Luiz Jardim de Moraes Wanderley \\ Professor Adjunto da Faculdade de Formação de Professores da UERJ \\ lulawanderley@gmail.com
}

Artigo recebido em 21/09/2015 e aceito para publicação em 10/12/2015

DOI: $10.12957 /$ tamoios.2015.18751

Resumo

O presente artigo tem como objetivo estudar as transformações na geografia da mineração de ouro mundial a partir da década de 1970, período em que ganha força a globalização financeira. Assim, buscou-se problematizar o fenômeno da globalização financeira e seus efeitos espaciais e sobre a esfera produtiva; a oscilação do preço da commodity ouro em diferentes contextos de oferta e da demanda mundial e em momentos de expansões e crises nos mercados de capitais e nas principais economias nacionais; por fim, analisaram-se as tendências de avanço e retração da extração mineral e seu deslocamento entre diferentes países e regiões ao longo das últimas quatro décadas. Apontamos, principalmente, que há no período analisado, certo descompasso entre a oscilação da extração mineral e o preço no mercado internacional e que também a mineração de ouro está num processo crescente de difusão para múltiplos países extratores, em especial nos países periféricos. No entanto, se encontra cada vez mais oligopolizada em poucas grandes mineradoras transnacionais.

Palavras-chave: Ouro, Mineração, Globalização financeira, commodities, Geoeconomia.

Abstract This paper analyzes the changes in the geography of world gold mining industry, since the 1970s, period in which leverages the financial globalization. We problematize the phenomenon of financial globalization and its spatial effects and consequences on the productive economy; the gold commodity price fluctuations in different contexts of the world offer and demand and in period of expansions and crises in capital markets and in the major national economies; Finally, we analyzed the advancing and retraction trends of the gold mining industry and its displacement between different countries and regions over the past four decades. We concluded that during the analyzed period, there was a mismatch between the oscillation of mineral production and the commodity price in the international market and also that the gold mining industry is an increasing diffusion process for several producing countries, especially in peripheral countries. However, this industry is increasingly oligopolistic in a few large transnational mining companies.

Keywords: Gold, Mining Industry, Financial globalization, commodities, Geoeconomics. 


\section{INTRODUÇÃO}

No século XX, o ouro passou a vigorar entre as commodities negociáveis em bolsas de mercadorias e futuros. Desde a década de 1970, o grau de importância e de influência geopolítica da extração mineral e das reservas do metal aurífero sobre a economia e a política mundial, aparentemente, diminuiu. Isto transformou o ouro numa commodity mais parecida com as outras, servindo fundamentalmente como matéria-prima para a indústria de joias e para indústria eletroeletrônica e como mais um ativo financeiro volátil. Os papéis em dólar assumiram a função de principal reserva de valor do mundo, em particular, para os Bancos Centrais nacionais. Com o câmbio flutuante estabeleceu-se uma tendência de grande volatilidade dos preços das commodities no mercado internacional (SERRANO, 2004).

O metal aurífero não é um bem de domínio exclusivo dos Estados. Pelo contrário, pois sua função primeira, na atualidade, é de mercadoria, ou melhor, commodity com preço determinado internacionalmente em bolsa, sob forte influência do capital financeiro. Devemos destacar, no entanto, que em muitos países, inclusive no Brasil, a propriedade sobre os recursos minerais ainda é do Estado (EMEL et al, 2011). Em geral, os Estados atuam como agentes reguladores - que exercem controle sobre as jazidas minerais e ditam quem, como, quando e quanto se extrai - e como compradores oficiais ou exclusivos do metal para fim de reserva cambial $^{1}$.

Muitas das questões que concernem ao metal aurífero e seu preço estão para além dos territórios nacionais, onde outros atores hegemônicos - grandes mineradoras, bancos transnacionais, fundos de investimentos, indústria joalheira, agentes financeiros de grande porte, agentes das redes ilegais, etc. - também integram a geometria do poder do sistema global do ouro junto com os Estados Nacionais (MASSEY, 2000). Os processos geoeconômicos ligados ao metal aurífero produzem fluxos transnacionais (mercadoria, capital, informação e pessoas) cujos efeitos se materializam sobre os territórios nacionais, na forma de aumento da extração e exportação de ouro, investimentos em commodities e em projetos de mineração, especulações no mercado financeiro e no setor mineral, circulação de trabalhadores, capital e informação etc. Deste modo, as lógicas do mercado geram implicações sobre os processos socioespaciais regionais, enquanto os Estados seguem operando, sobretudo, como agentes reguladores submetidos à lógica privada (EGLER, 2007; 2009). O capital financeiro, assim como em toda economia contemporânea (CHESNAIS, 1996), assume participação central no setor mineral. Provêm do sistema financeiro, inclusive, os recursos para investimentos em pesquisas minerais, em novos empreendimentos, em infraestruturas de logística, além dos lucros em transações financeiras - contratos futuros, swaps, opções, hedging, etc. (SHERVAL, 2009). 
Karl Marx (1858) já apontava que o ouro era uma mercadoria como nenhuma outra, pois tinha o privilégio de servir de instrumento de troca universal. Ou seja, tinha a dupla função de funcionar como dinheiro e como mercadoria. Hoje em dia, o ouro porta-se como uma commodity complexa, que contém diversificadas utilidades e qualidades. Primeiramente, ela possui tanto valor de uso como de troca, servindo como matéria-prima e como valor monetário de reserva. O metal serve à indústria joalheira, à indústria de alta tecnologia, à indústria médicaodontológica e como reserva de ativo financeiro para países, bancos, empresas e outros investidores, pessoas jurídicas ou físicas. A diversidade de usos confere ao metal uma condição bastante específica em momentos de crise econômica ou no momento de variação do preço da commodity ouro.

Durante crises econômicas, que afetam diretamente a capacidade de consumo global, tende a haver redução no consumo de joias. Em contrapartida, as crises monetárias podem resultar no direcionamento dos investidores do mercado financeiro para o ouro, enquanto ativo mais protegido às desvalorizações das principais moedas internacionais. A segurança em adquirir um bem material com valor de mercado constituído. Assim, existe certo equilíbrio na demanda pelo metal, o que justifica a pequena variação entre oferta e demanda de 1970 a 2010. Porém, as joias continuam sendo importante destino do metal, o que torna o setor joalheiro determinante na flutuação da demanda.

Diversos fatores exercem influência sobre a extração mineral, tais quais: o preço do mineral, custo de exploração, as formas de regulação, taxação dos Estados nacionais e a descoberta de novos depósitos viáveis tecnológica e economicamente. Nem sempre um depósito contém rentabilidade frente aos custos de extração, ao preço vigente do metal nos mercados e as taxações dos Estados em determinado momento e localidade. A temporalidade da mineração industrial não consegue acompanhar o tempo rápido da variação do preço nos mercados financeiros. Enquanto a volatilidade do preço da commodity, em bolsa de valores, ocorre em meses ou poucos anos, os investimentos de reabertura de uma mina, de descoberta de novas reservas ou de implantação de um novo empreendimento com a infraestrutura necessária, requerem médio e longo prazo para serem executados.

Com o presente artigo buscamos compreender as redes de produção global do ouro no contexto da globalização financeira e seu comportamento com o fim da paridade Dólar-Ouro na década de 1970, quando passou a funcionar como mercadoria livremente negociada em bolsa e utilizada como ativo financeiro e matéria-prima para indústria joalheira, eletrônica e médicaodontológica. Contemporaneamente, o ouro constitui-se como uma commodity complexa, que contém múltiplos valores e, sobre a qual, diversos atores operam influindo sobre o preço estabelecido nos mercados financeiros e de trocas corrente. Buscamos, portanto, destrinchar a complexidade que envolve a volatilidade do preço do metal, para posteriormente entender os 
efeitos sobre a economia e o espaço. Assim, analisamos a evolução do preço do metal, no último meio século, e os desdobramentos sobre a mineração de ouro na escala global.

\section{EFEITOS ESPACIAIS DA GLOBALIZAÇÃO FINANCEIRA}

O panorama político-econômico da globalização financeira articulado aos grandes avanços técnicos e científicos das telecomunicações e dos transportes desenhou uma nova geografia a partir de 1970 (BENKO, 1994; 2002; HARVEY, 1989; 2010; O'BRIEN, 1992; BUNKER, 2003). Os processos de globalização, neoliberalização e financeirização levaram alguns pesquisadores, como Richard O'Brien (1992) e Paul Virilio (2000), a falarem da redução da importância do espaço, ou até mesmo do fim da própria geografia, por conta da exacerbação da fluidez e dos fluxos de capitais, mercadorias e pessoas ao redor do globo. Outros autores contemporâneos, como Kenichi Ohmae e Bertrand Badie, ressaltaram ainda o "fim do Estadonação" e o "fim do território" (HAESBAERT, 2004)

Para Richard O’Brien (1992), preocupado em desvelar os processos concernentes ao sistema financeiro global, a geografia deixou de ter importância com a capacidade de transformação da computação, o desenvolvimento das tecnologias de comunicação e a liberalização financeira dos mercados. Intensificaram-se os fluxos de capital pelo mundo, atribuiu-se maior autonomia aos agentes do mercado financeiro globalizado e diminuiu a capacidade de intervenção do poder territorial dos Estados sobre os processos socioespaciais. Esta análise está equivocadamente sustentada na compreensão de geografia como sinônimo do território dos Estados-nações e na hipótese, pouco fundada, de que a importância dos Estados nacionais estaria se extinguindo no período da globalização neoliberal. Recentemente, Richard O’Brien e Alasdair Keith (2009) assumiram que existem fatos novos em andamento que contradizem a antiga hipótese do fim da geografia. Em resposta as crises econômicas e financeiras do começo do século XXI vislumbra-se uma retomada da maior interferência regulatória dos Estados sobre os fluxos de capitais, afirmaram os próprios.

Paul Virilio (2000) segue em outro sentido teórico, discorrendo sobre um espaço sem limites físicos em função das redes técnicas, científicas e informacionais. Para ele, as novas tecnologias de telecomunicação e de transporte teriam rompido com as limitações e as particularidades do espaço físico e construíram uma "meta-geofísica". A nova esfera de interações cibernéticas monopoliza as atividades econômicas nacionais e destrói as culturas situadas no espaço físico a tal ponto, que o controle sobre tempo seria estrategicamente mais importante que o controle sobre o espacial. O equívoco, no que o autor sugeriu como o fim da geografia, está no menosprezo dos processos locais e das particularidades, em detrimento de uma globalização homogeneizadora. Ou ainda, na incompreensão de que as interações em rede 
pressupõem uma espacialidade e que o encurtamento das distâncias não corresponde ao fim do espaço físico ou ainda da geografia (HAESBAERT, 2004).

Os processos de neoliberalização e financeirização do espaço, a partir de 1970, foram constituídos conjuntamente e provocaram o gradativo aumento do poder do dinheiro e do mercado financeiro desde a vida cotidiana dos indivíduos até o sistema financeiro internacional (FRENCH; LEYSHON; WAINWRIGHT, 2011; PECK; TICKELL, 2002). O capitalismo contemporâneo foi se definindo pelo predomínio de aplicações do capital excedente na órbita financeira, em detrimento de investimentos no setor produtivo (CHESNAIS, 1996). As formas não produtivas de geração de riqueza têm caráter rentista e quase não produzem riqueza real. As transações de ações de corporações e fundos, de imóveis e terras, de títulos públicos e de contratos de mercadorias e derivativos estão incluídas dentre as principais formas de reprodução do capital de maneira não produtiva (NATAL, 2011). Com a liberalização do mercado de câmbios e a desregulação dos fluxos de capitais entre mercados nacionais, os agentes do mercado financeiro passaram a operar sobre os vários tipos de volatilidade em qualquer lugar e a partir de qualquer lugar, almejando alcançar ganhos elevados em curto prazo. No entanto, essas operações estão sempre submetidas aos altos riscos de perdas, o que transformou o mercado financeiro num grande cassino eletrônico global (CASTELLS, 1996).

O tempo na lógica financeira do mercado representa dinheiro. Ou melhor, o tempo cria e multiplica dinheiro, manipulando o futuro a partir de projeções do tempo presente. Como salientou Manuel Castells (1996),

\section{(...) um número significativo e crescente de transações financeiras baseia-se na geração de valor a partir da captação do futuro nas transações presentes, como nos mercados de futuros, opções e outros mercados de capitais de derivativo. Juntos, esses novos produtos financeiros aumentam drasticamente a massa de capital nominal vis-à-vis os depósitos e ativos bancários, de forma que é apropriado dizer que tempo gera dinheiro, à medida que todos apostam no/e com o dinheiro futuro previsto nas projeções dos computadores (p. 528).}

Um dos mais preocupantes reflexos da globalização financeira é que cada vez mais se investe em ativos fictícios, sem que exista qualquer correspondência de base material e espacial (PAULINO, 2014). Mesmo no mercado de capitais e mercadorias quase não há correspondência direta dos ativos negociados com uma base material ou espacial. Até mesmo as mercadorias negociadas não existem no tempo presente, pois são projeções de uma materialidade futura que, de preferência, não devem ser entregues a quem adquiriu o contrato de compra, tendo em vista que muitas vezes ao negociador só interessa especular, não havendo nenhum interesse no produto em si.

O mercado financeiro de commodities são uma das expressões mais contundente da financeirização, pois corresponde a transação imaterial (sem trocas físicas) de bens materiais espacializados e temporalizados. As commodities, enquanto recursos de base natural, 
obviamente têm geograficidade, como demonstra o livro Geographies of Commodity Chains (2004) de Alex Hughes e Suzanne Reimer, e utilidade prática. Todavia, quando negociadas em bolsa de valores, as commodities não estão referenciadas a uma determinada localidade e um momento de extração/produção específico. Trata-se de uma mercadoria aleatória, sem história e geografia, negociada em forma de contratos por alguém licenciado a operar seguindo as normas do mercado (no caso do ouro, fundidores e fornecedores de ouro, joalherias, mineradoras e empresas assemelhadas) e comprada por indivíduos ou instituições interessadas em rendimentos especulativos ou para utilizá-la para fins produtivos.

Os arranjos e lógicas no âmbito do sistema financeiro estão, em alguns casos, quase desligados do mundo material da produção no espaço geográfico ou da economia real. Essa exacerbada imaterialidade do capital, amplamente difundida e desregulada, permite que haja manipulações e erros, que acabam gerando riscos e produzindo crises cíclicas nos mercados financeiros (KRUGMAN, 2009; PAULINO, 2014). Contudo, o mercado financeiro não se encontra apartado do mundo real, pois se trata de uma construção dos governos, corporações e indivíduos, ao mesmo tempo em que os influenciam (FRENCH; LEYSHON; WAINWRIGHT, 2011). Várias crises financeiras recentes se originaram de problemas concretos do espaço social, assim como algumas crises de origem financeira refletiram intensamente nas economias reais (HARVEY, 2010). François Chesnais (1996: p 246) explicou a inter-relação entre as esferas financeira e real, no que concerne a autonomia e interdependência entre elas:

(...) [O]s termos "autonomia", "autonomização" etc. devem ser utilizados com muito cuidado. É verdade que parte elevadíssima das transações financeiras verifica-se no circuito fechado formado pelas relações financeiras especializadas. Mas isso não quer dizer que não existam vínculos muito fortes, e sobretudo de grande alcance econômico e social, entre esfera de produção e circulação e a das finanças. A esfera financeira nutre-se da riqueza criada pelo investimento e mobilização de uma força de trabalho de múltiplas qualificações. Uma parte, hoje elevada, dessa riqueza é captada ou canalizada em proveito da esfera financeira, e transferida para esta. Somente depois de ocorrer essa transferência é que podem ter lugar, dentro do circuito fechado da esfera financeira, vários processos de valorização, em boa parte fictícios, que inflam ainda mais o montante nominal dos ativos financeiros.

O sistema financeiro não se comporta como mero espelho da economia real, nem todos os acontecimentos no interior do sistema financeiro global alcançam as economias locais, regionais e nacionais. Às vezes, quando um fenômeno se transfere do financeiro para produtivo, ele pode chegar com atraso ou com magnitude diferente, o que demonstra certa autonomia entre as esferas do financeiro e do produtivo (CORPATAUX; CREVOISIER; THEURILLAT, 2009). Em geral, as atividades produtivas, majoritariamente as intensivas em capital, tendem a reagir lentamente às tendências de preços, demandas e transações do mercado financeiro. A volatilidade frequente dos mercados de capitais só encontra resposta direta na esfera da produção quando são duradouras ou agudas. 
Durante tendências mais duradouras no sistema financeiro há maiores possibilidades de feitos do mundo financeiro sobre o espaço econômico produtivo, com reflexos para o bem e para o mal. É inquestionável que as desvalorizações cambiais, as variações dos preços das commodities e a própria insegurança político-financeiras dos Estados, no longo prazo, se traduzem em efeitos representativos sobre a economia real e os arranjos sociopolíticos e espaciais de países e regiões. Ao analisar as maiores crises econômicas de 1970 a 2010 - crise do Subprime americano de 2008, crise dos Tigres Asiáticos entre 1997-98, nos países nórdicos em 1992 e no Japão nos anos 1980 -, David Harvey (2010) observou que elas estiveram sustentadas em bases materiais das economias regionais, em particular, nos mercados de terra urbana e nos problemas de habitação das grandes cidades. As crises fundadas na economia real tendem a ser mais longas e intensas que as crises originárias dos mercados de ações ou bancário. Isto se deve, em parte, ao fato delas estarem atreladas aos créditos de alto risco e longo tempo de retorno mas, sobretudo, por emergirem de problemas sociais estruturais da sociedade capitalista, que não se solucionam por meio de operações matemáticas e financeiras.

A ideia de que os processos financeiros globais afetam invariavelmente os espaços sociais ao redor do mundo está contida num discurso político-ideológico mais amplo, que pressupõe a passividade das escalas nacionais, regionais e locais sobre a global. Esse discurso do capitalismo globalizado como processo explicativo da produção do espaço atual em todas as escalas geográficas, nos traz tanto problemas teórico-analíticos, como da práxis social. A concepção teórica da globalização como processo socioespacial transcendente a outros, e que assim legitima a supremacia da escala global sobre as outras escalas geográficas, consiste em uma construção social e ideológica do conceito de escala a partir de uma noção hierárquica (BRENNER, 2001). A globalização, enquanto discurso e prática, vem servindo para naturalizar e reproduzir as formas de dominação exercidas por grupos dominantes e, principalmente, pelo imperialismo americano, através das políticas neoliberais, ao longo do último meio século (HARVEY, 2003; MARSTON, WOODWARD; JONES III, 2007).

\section{VOLATILIDADE DO PREÇO DO OURO NO MERCADO FINANCEIRO INTERNACIONAL}

Desde a década de 1970, quando o sistema monetário internacional deixou de estar amparado em bens materiais de ouro, o metal apresentou apenas dois momentos de variação exacerbadamente fora do preço médio (Figura 1). A média de cotação das últimas quatro décadas (1971 a 2014) aproximou se dos 500 dólares a onça-troy. A estabilidade é relativa, tendo em vista que se está falando de uma commodity de preço flutuante, como qualquer outra, negociada diariamente em mercados financeiros (em mercados futuros, de opções ou 
derivativos) e a mercê dos "humores" e negociações dos players globais. Deste modo, a relativa estabilidade corresponde a um movimento permanentemente variável do preço, cujos resultados foram de baixas perdas ou rentabilidades.

Com o fim da conversibilidade do dólar em ouro, em 1971, a volatilidade do metal propiciou as variações anuais extremas de $101,7 \%$ positivos e $25,3 \%$ negativos. A maior alta sucedeu em 1980, deflagrada pela crise do Segundo Choque do Petróleo, que inclusive levou a média de inflação dos Estados Unidos à maior taxa anual do último meio século (162,9\% no ano ou média mensal de 13,58\%). Já a maior queda ocorreu no ano seguinte, em função do rearranjo do mercado da commodity aurífera frente ao crescimento acelerado do preço, que avançou quase 400\% em quatro anos, em reação à elevação dos juros nos Estados Unidos da América - EUA e o aumento da oferta de ouro dos soviéticos (GOVETT; GOVETT, 1982). A média de valorização anual do preço do metal ficou em 11,7\%, nos 42 anos de história do ouro flexível, o que representada um bom ganho no período, três vezes superior a média da inflação anual americana no mesmo período.

$\mathrm{O}$ aparente aspecto de retorno satisfatório em investimentos em ouro não vigorou homogeneamente ao longo do período pós-convertibilidade. O ouro na maior parte do último meio século foi reconhecido como investimento seguro e conservador, sem grande retorno e protegido da inflação das moedas, em especial do dólar. Além disso, trata-se de um ativo que historicamente reage positivamente às adversidades no mercado financeiro (BAUR; LUCEY, 2010; BAUR; McDERMOTT, 2010; BAUR, 2011). Para fins esquemáticos, se dividiu as tendências no preço do ouro em quatro momentos após o fim do Padrão Ouro-Dólar: dois ciclos de valorização, um de relativa estabilidade e outro de depreciação (Figura 1). 


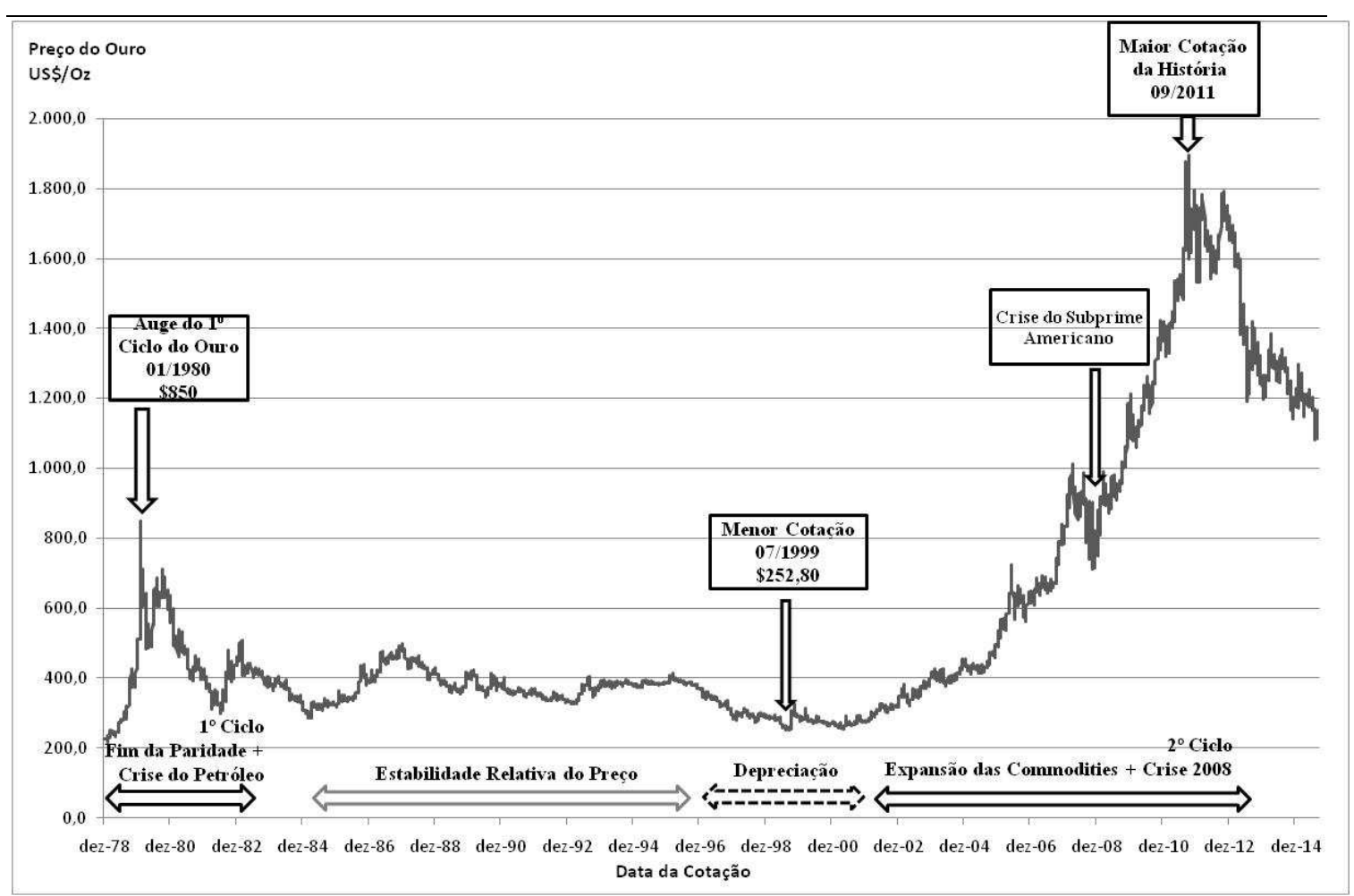

Figura 1: Histórico do Preço do Ouro no Mercado Financeiro (1978-2014)

Fonte: World Gold Council

Antes do ouro flexível, o preço do minério apresentava pouca ou nenhuma variação no mercado aberto. Os preços praticados seguiam o equilíbrio estabelecido pelo Banco Central do país com a moeda corrente internacional, calculados a partir da relação entre o preço da moeda corrente e a quantidade de reserva de ouro que a nação hegemônica detinha. O Banco da Inglaterra, primeiramente entre 1870 e 1914, era o principal definidor do preço do metal, papel assumido pelo Banco Central dos Estados Unidos, após a Segunda Guerra Mundial. Os Bancos Centrais nacionais adquiriam a maior parte do ouro ofertado no mercado, o que também permitia o exclusivo controle do preço por parte da esfera estatal, já que o mercado paralelo movimentava um volume pouco significante do metal. Neste contexto, o preço se manteve, de 1934 a 1968, próximo aos 35 US\$/Oz. O baixo preço do metal, no Padrão Ouro-Dólar, estimulou o consumo de joias de ouro entre as classes médias dos países centrais (GREEN, 1999; 2007). Em 1970, $72 \%$ da demanda provinham da indústria joalheira e $12 \%$ de investimentos e reservas cambiais (Figura 2). 


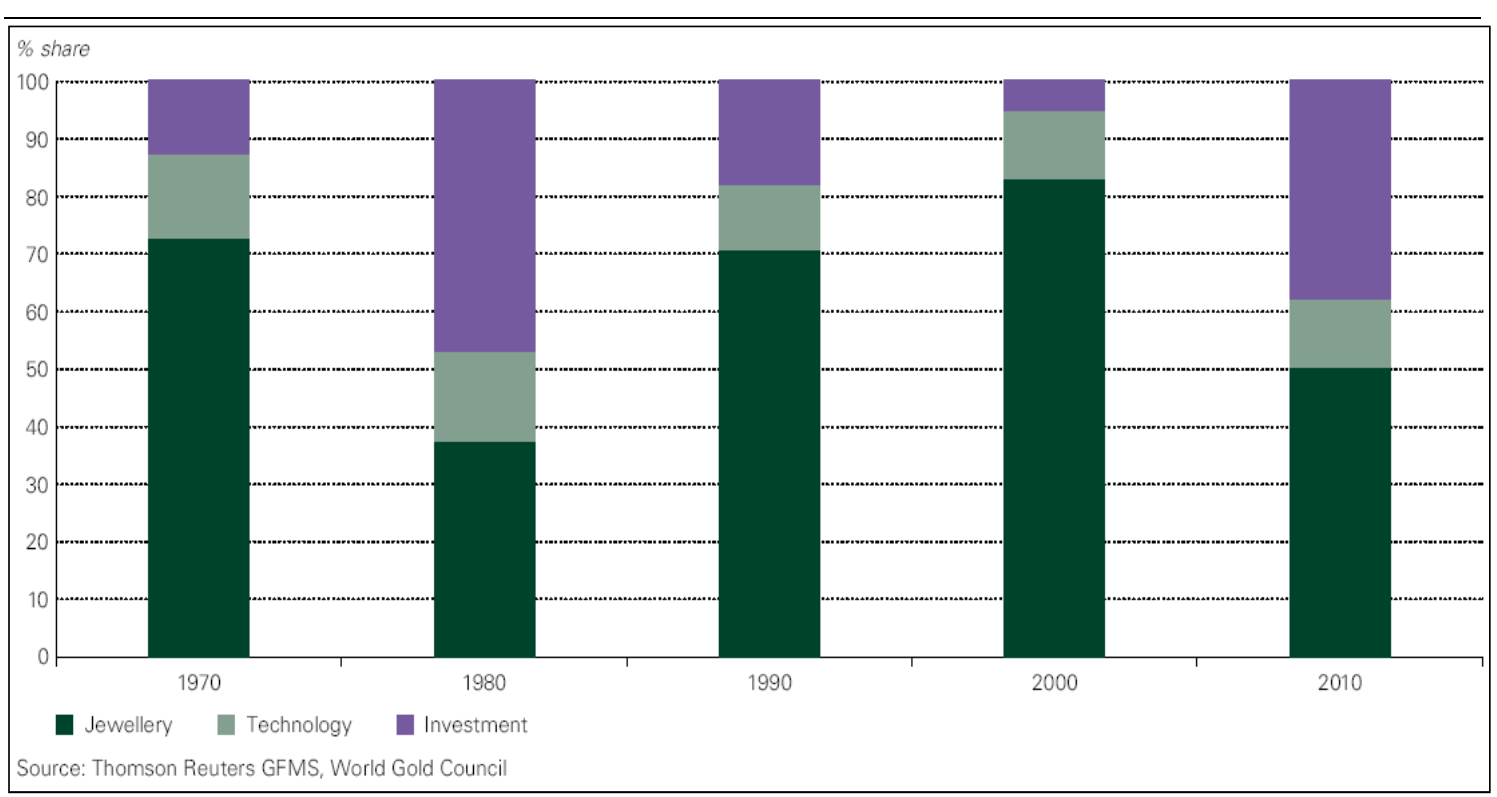

Figura 2: Distribuição de Demanda de Ouro por Finalidade (1970-2010)

Fonte: Extraído de World Gold Council (2011)

O primeiro ciclo do preço do metal iniciou com o fim definitivo do padrão monetário Ouro-Dólar, em 1971. A quebra da conversibilidade entre o metal e a moeda estadunidense permitiu que o metal fosse negociado como qualquer outra commodity em bolsa de valores, sem preço fixo ou preestabelecido pelos Bancos Centrais nacionais. Logo de início, o mercado financeiro operou em favor do mineral e contra o dólar. O novo sistema monetário de câmbio flutuante imposto pelo EUA e sua moeda estavam em suspeição. Enquanto o papel da moeda estadunidense declinava nas transações comerciais, financeiras e na participação nas reservas dos Bancos Centrais (BELLUZZO, 1999), o metal subia de preço favorecido pela especulação e pelas pressões inflacionárias (GOVETT; GOVETT, 1982). Em 1980, os investimentos financeiros e em reservas de valor corresponderam à maior parte da demanda do metal (48\%), enquanto o setor joalheiro absorveu $38 \%$ (Figura 2), revertendo o padrão anterior majoritariamente joelheiro.

Outra causa preponderante do rápido avanço do preço do ouro, na década de 1970, foi a política de elevação do preço do petróleo, conduzida pela Organização dos Países Produtores de Petróleo - OPEP e as tensões políticas nos países petroleiros do Oriente Médio - Revolução Iraniana (1978-79); Crise do Afeganistão (1978-79); Guerra Irã-Iraque (1980-88). A desmaterialização do sistema monetário internacional, no princípio da década de 1970, e os dois choques do petróleo, em 1973 e 1979, contribuíram para formar uma conjuntura de instabilidade e incerteza política e econômica, que conduziu à valorização do ouro na década de 1970 . O primeiro ciclo de alta alcançou o ápice de 850 dólares a onça-troy em janeiro de 1980. Contudo, o preço do ouro superior a 800 dólares não se sustentou. Durou apenas dois dias de pregão nas Bolsas de Commodities de Nova York e Londres. Em menos de um mês, o metal já batia cotações inferiores a $700 \mathrm{US} \$ / \mathrm{Oz}$. 
Em 1982, o ouro atinge os 400 dólares a onça-troy, preço médio que seguiu como parâmetro por aproximadamente 15 anos. Este período corresponde ao momento de maior estabilidade no preço da commodity aurífera, que permitiu à ascensão das corporações mineradoras transnacionais, após o fim do preço fixo ${ }^{2}$. Mesmo que tenha havido oscilações ao longo dos anos, o preço do metal se manteve perto dos $400 \mathrm{US} \$ / \mathrm{Oz}$. A oscilação no preço foi ainda menor entre os anos de 1987 e 1997, quando pode se considerar ter havido relativa estabilidade, com o preço se mantendo entre US\$350 e US\$450. A baixa oscilação e a relativa estabilidade propiciaram aos investidores um ambiente protegido das perdas com a inflação, mesmo assim a tendência foi a substituição do ouro por outros investimentos mais rentáveis no curto prazo. Durante essa fase, se expande rapidamente a demanda da indústria de joias e de tecnologia, em substituição ao uso do metal como reserva monetária e ativo financeiro. Em 1990, o mercado de joias consumia $70 \%$ da oferta de ouro novo no mercado e os investimentos apenas $19 \%$ (Figura 2).

Entre 1997 e 2001, o ouro passou pelo período de mais longa depreciação desde o começo do preço flexível, alcançando o patamar mínimo de 252,80 dólares por onça-troy, em setembro de 1999. Este preço representava o mesmo valor do metal em 1973, considerando a inflação do período. O ciclo de desvalorização do metal ocorreu, segundo John Young (2000), por excesso de oferta no mercado. Para o analista, a venda contínua das reservas dos bancos centrais e os subsídios dado às mineradoras para aumentar a extração nos EUA e em outros países mineiros fizeram parte de uma política orquestrada para depreciar o ouro frente às moedas nacionais e a outros investimentos. Outro fator está relacionado à boa fase da economia americana, ao dólar forte, à baixa inflação no país e no mundo e ao fortalecimento do mercado financeiro. Com a superoferta e o baixo preço, o ouro estaria deixando definitivamente seu valor monetário, assumindo o caráter de commodity comum (YOUNG, 2000). No âmbito do mercado financeiro de ouro, acrescentamos a desconfiança dos investidores nas mineradoras juniors ${ }^{3}$, por conta da fraude da canadense Bre-X, e a política agressiva de hedge $e^{4}$ por parte das grandes mineradoras, que buscavam proteger-se da variação negativas do preço (VALE; HERRMANN, 2002). Até 2003, a demanda pelo metal sofreu ainda leve decrescimento e esteve progressivamente mais concentrada na indústria joalheira. Em 2000, o consumo em joias e as aplicações financeiras correspondiam a $84 \%$ e $4 \%$ do metal ofertado, respectivamente.

De 2002 a 2011, o mercado financeiro global vivenciou novo crescimento exponencial do preço do ouro, que atingiu a marca histórica de 1.895 US\$/Oz, em setembro de 2011 (Figura 1). A tendência de valorização chamou a atenção por ser a aquisição do metal um dos investimentos mais rentáveis no mercado financeiro durante a crise internacional, que se instalou na metade de 2008. Desde então, até 2012, o ouro foi utilizado como commodity de alta rentabilidade e alta volatilidade para investidores audaciosos e especuladores nas bolsas de 
mercadorias e futuros (BAUR, 2011). No mais, a valorização de longa durabilidade representa uma grande oportunidade para os mineradores de pequeno, médio e grande porte em diversas regiões do mundo.

O segundo ciclo de valorização do ouro, que teve início em 2002 e dura até o momento atual, se explica por dois processos distintos e separados em duas fases. Aparentemente, a aguçada evolução do preço não se explica completamente pela lógica da oferta e da demanda. A primeira fase teve início em 2002 e seguiu até a crise do Subprime, no mercado imobiliário do EUA, em 2008. Já a segunda começa a partir de meados de 2008, com a crise americana, e prossegue até 2011, com o alastramento da crise pelo mundo, principalmente na Zona do Euro. Não há certezas sobre o fim do segundo ciclo de valorização do ouro. No entanto, observamos a tendência à redução no preço a partir de 2012, que se acentuou ainda mais em 2013, com a depreciação de 15,4\% no ano. O metal seguiu declinando lentamente nos anos de 2014 e 2015.

Até 2008, a valorização do metal aurífero esteve associada ao fenômeno de aumento do preço das commodities em geral, com destaque para o petróleo (BECKMANN; CZUDAJ, 2013; LE; CHANG, 2011; SHAFIEE; TOPAL, 2010; ZHANG; WEI 2010). A explicação central está no incremento do consumo dos países emergentes, principalmente Índia e China, que resultou no "Boom das Commodities" nos anos 2000. No caso do ouro, a Índia, a China e outros países emergentes expandiram os mercados internos de joias e de compra de barras e moedas de ouro na década de 2000. Os dois países asiáticos se tornaram os maiores consumidores de ouro no mundo desbancando os EUA, tanto em joias, como em barras e moedas, correspondendo juntos a mais da metade do consumo global (WGC, 2011). O crescimento do consumo chinês e indiano está inserido no contexto do alargamento da classe média mundial, que quase triplicará de 1,8 bilhão, em 2009, para 4,9 bilhões de indivíduos até 2030 (FUKUYAMA/PNUD, 2013). Estimamos que assim haverá incremento da massa de consumidores, em particular, do metal, nas próximas décadas. Em 2007, antes da crise financeira global, a demanda mundial por ouro ainda se encontrava predominantemente na indústria joalheira, com $68 \%$ das compras.

Associado ao crescimento da demanda do consumo mundial, outros importantes aspectos que contribuíram para o avanço do preço, especificamente, das commodities minerais estão relacionados à existência de jazidas minerais, à tecnologia de extração e ao custo de extração. Identifica-se que há o esgotamento das melhores reservas minerais do mundo (com maior teor, de mais fácil extração e melhor localizadas) e também que existe a possibilidade de escassez de alguns minérios no médio prazo (MILANEZ, 2012). A queda vertiginosa da quantidade extraída das ricas minas de ouro da África do Sul é um bom exemplo. Os sulafricanos que ofertavam mil toneladas (32 Moz) de ouro, ou quase $70 \%$ do minério extraído do mundo, em 1970, ofertaram apenas 5\% do metal novo em 2013 ou 145 toneladas (4,7 Moz). A saturação das melhores jazidas reflete diretamente sobre o custo de prospecção e operacional. 
Os gastos em pesquisa mineral aumentaram, no entanto, as descobertas de reservas de alto teor se tornaram raras. O custo de extração, do mesmo modo, vem encarecendo, pois é preciso aprimorar a tecnologia mineral para extrair de maneira rentável as jazidas de menor teor ou de ocorrência geologicamente mais difícil. Outro fenômeno gerado pelo aumento do preço e da escassez relativa é a expansão da fronteira mineral das mineradoras para áreas remotas do globo (SHERVAL, 2009), onde há carência de infraestrutura e se demanda mais investimento para implantação de projetos de mineração.

Obviamente, se incorporou ao crescimento da demanda mundial e a exaustão das minas mais ricas, um forte componente especulativo, próprio ao mercado de capitais. Com a maior financeirização das commodities, negociadas diariamente em bolsas de mercadorias e futuros pelo mundo há a tendência de maior volatilidade do preço por conta de pressões especulativas. Além disso, a mineração industrial, por ser intensiva em capital, enfrenta dificuldades em ajustar a oferta dos minerais às variações de preços e da demanda no curto prazo.

A partir de meados de 2008, momento de alastramento da crise imobiliária americana, o índex do ouro nas principais bolsas internacionais de commodities (Nova Iorque e Chicago) continuou traçando caminho progressivo, enquanto as outras commodities sofreram acentuadas perdas, recuperadas modicamente nos anos subsequentes (Figura 3). A guinada no preço do ouro, a partir da instauração da crise financeira global, pode ser explicada, em parte, pelo descrédito das políticas monetárias das potências financeiras globais e pelo alto grau de endividamento dos Estados Unidos e de países da Europa, o que desvalorizou as principais moedas e aumentou a inflação. Desde então, o ouro novamente deixava de ser uma commodity comum e retomava seu sentido monetário, atuando como uma alternativa mais segura à vulnerabilidade das moedas reserva (dólar, euro e libra), abaladas pela crise financeira global.

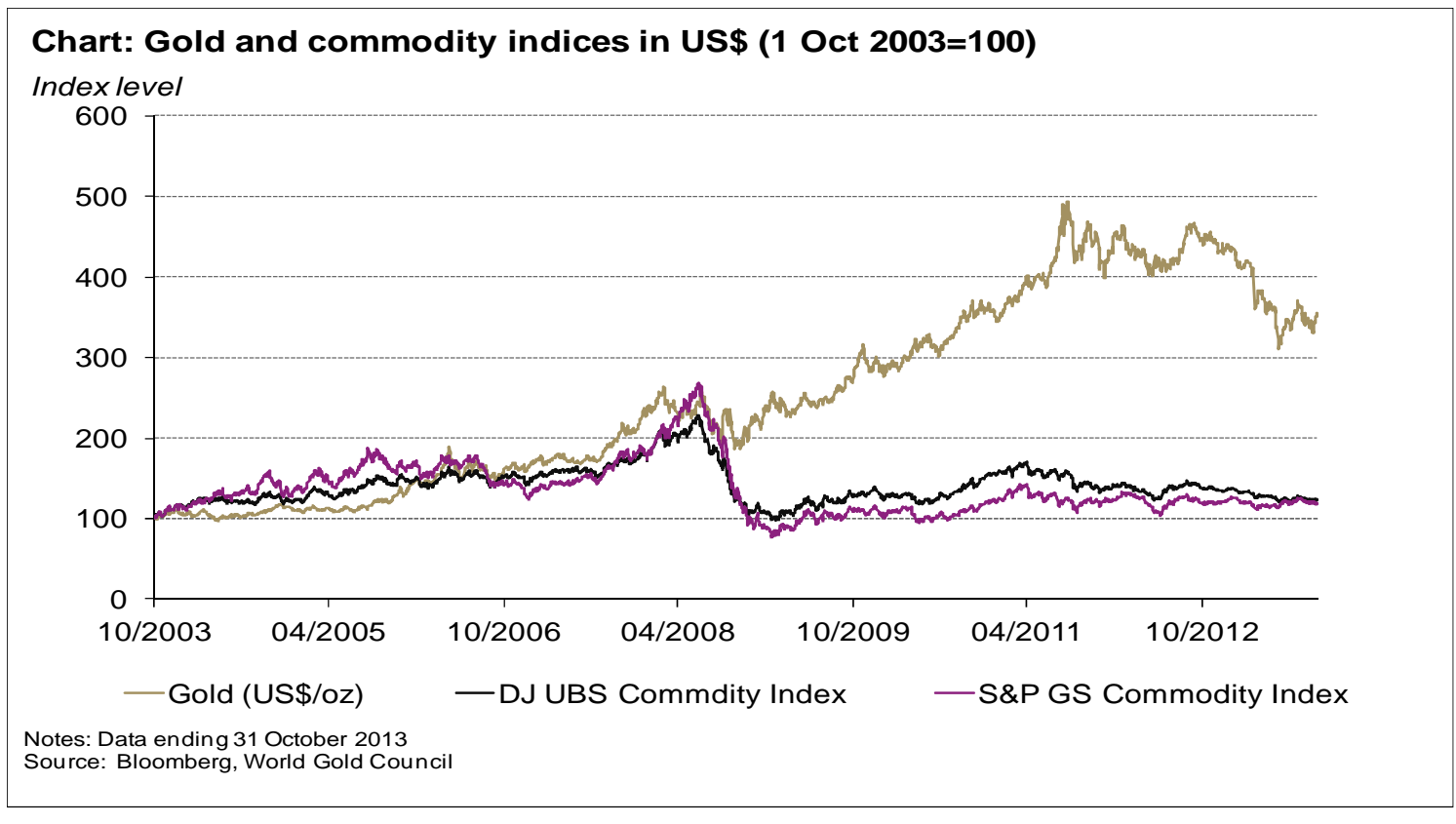


Figura 3: Índex do Ouro e das Commodities em Bolsa de Mercadorias e Futuro (2003-2013)

Fonte: Extraído de World Gold Council

Quando a crise chegou a níveis preocupantes diante da redução da credibilidade do sistema monetário global, muitos investidores e até a mídia especializada apontaram efusivamente a aquisição de metal como alternativa segura de ativo frente à instabilidade das moedas e das commodities. A desconfiança para com as moedas mais fortes se deveu a incerteza quanto à solvência da economia de vários países centrais com elevados endividamentos públicos, inclusive os EUA. No que tange as commodities, a incerteza estava na durabilidade da crescente demanda e do crescente preço com o prenúncio de uma depressão econômica mundial, que afetaria inclusive os mercados emergentes. Na primeira década do século XXI, o investimento em ouro representou a realização de altos lucros para os detentores de reservas do metal e para os especuladores do mercado financeiro internacional, com retorno de mais de $650 \%$ no período. A partir do final de 2012, após 10 anos de valorização, a evolução do preço do metal no mercado financeiro inverte para a tendência de queda, demonstrando o esgotamento do ciclo de valorização.

Em suma, no segundo ciclo de valorização do ouro (2001-2013), a expansão do preço aconteceu, na primeira fase, até a crise de 2008, pela valorização das commodities em geral, relacionada ao incremento na produção da indústria joalheira e ao consumo de joias, barras e moedas de ouro. Os países emergentes foram os maiores estimuladores da elevação da demanda, em particular a Índia e a China, sendo que o consumo indiano sempre foi significativo. Na segunda fase, a partir de 2009, a demanda industrial pelo mineral recuou pouco e acrescentou-se a incorporação de pressões especulativas e ainda o incremento das aplicações financeiras em ouro no mercado financeiro. Após o estouro da crise financeira global, o metal teve altas taxas anuais de crescimento e a demanda esteve cada vez mais vinculada aos investimentos financeiros (moedas, barras, reservas em bancos centrais e fundos de investimentos). Em 2012, os investimentos financeiros suplantaram o uso em joias, com respectivamente $47 \%$ e $43 \%$ do ouro novo ofertado, assim como sucedeu no auge do primeiro ciclo de valorização do ouro, em 1980.

O processo de valorização do ouro, neste princípio de século, seguindo na contramão das demais commodities, deve ser compreendido a partir dos elementos teóricos sobre as crises no capitalismo contemporâneo, fornecidos por David Harvey (2010). O autor elucida que o capital não soluciona a crise, mas sim, contorna os problemas gerados pelo próprio capitalismo por meio de novas maneiras de investir o excedente de capital. Dentre as maneiras de contornar as crises estão: a tomada de novos setores como prioritários; a inserção de novas regiões na economia, expandindo a fronteira geográfica do capital em busca de novos recursos, contingentes de trabalhadores e consumidores; e a inovação tecnológica, que não só permite a 
abertura de novas fronteiras como o surgimento ou ressurgimento de novos setores. Portanto, podemos interpretar que o mercado de ouro tenha servido nas crises do Subprime Americano (2008) e da dívida pública europeia (2010) como um novo meio de acumulação do capital, uma espécie de salvaguarda diante da generalizada crise financeira global (BAUR, 2011).

\section{EVOLUÇÃO E MUDANÇAS NA GEOGRAFIA DA MINERAÇÃO DE OURO GLOBAL}

Existem diversas variáveis que conduzem ao exame do fenômeno da mineração em diferentes escalas geográficas, que não só a cotação do mineral. Podemos afirmar, então, que as transformações na economia global nem sempre conduzem à resposta imediata no preço ou no mercado produtivo das commodities, como o ouro. Os períodos de baixa ou alta podem durar tempos longos ou mais ou menos curtos, às vezes insuficientes para que sejam sentidos os efeitos no setor produtivo. Ainda mais sobre a grande mineração, setor intensivo em capital, onde o tempo entre o capital investido e o retorno é bem mais demorado e os investimentos e projetos são planejados em médio e longo prazo.

Além do mais, as conjunturas nacionais e regionais/locais influem sobre a atividade mineral e as maneiras de apropriação dos recursos minerais, podendo até mesmo inibir ou contrariar as tendências globalizadoras. Vale lembrar, neste momento, um ponto que demonstra a importância das outras escalas na mineração, em particular a nacional. A commodity ouro é cotada invariavelmente em dólar. Todavia, no mercado nacional as negociações são mediadas pela moeda nacional corrente. Por isso, o preço variará também seguindo a cotação do dólar, que sofre influência direta das políticas monetárias nacionais.

Os efeitos da variação do preço nos mercados internacionais de commodities sobre a extração mineral industrial não é padronizada. Govett e Govett (1982) afirmaram que os diferentes tipos de depósitos, de método, de custo da extração e de vantagens locacionais fazem com que a resposta à cotação varie entre localidades e entre países. James Craig e Rimstidt (1998) enfatizaram que o ímpeto de extração responde à velocidade de descobertas, à quantidade de colaboradores, à disponibilidade de mão de obra, ao grau tecnológico, às ações governamentais e também ao preço do metal. Saroja Selvanathan e E.A. Selvanathan (1999), por outro lado, buscaram comprovar uma tendência de crescimento moderado da mineração quando se identifica o aumento sustentado do preço do metal no longo prazo. O mesmo argumentaram Ross Cullen e David Craw (1990) e Duane Rockerbie (1999) ao correlacionarem o impacto da variação do preço e do custo operacional sobre a atividade mineral. Nesta correlação, os autores constataram que o crescimento no preço do ouro, em consonância à manutenção dos custos, incentiva as mineradoras a potencializarem a extração e se moverem para depósitos menos ricos ou mais profundos. 
A evolução da extração de ouro no mundo no último meio século (Figura 4), sugere que a relação de causa e efeito entre variação do preço e variação da extração deve ser questionada e que outros elementos devem ser considerados, para compreender o avanço ou a retração da mineração. Por se tratarem de dados do volume extraído oficial, acreditamos que o volume pode ser ainda maior, acrescentando ainda parte da extração da mineração artesanal e da pequena mineração que, em geral, são fenômenos informais ou ilegais, pouco ou nada contabilizados.

O declínio do volume de ouro minerado, na década de 1970, pode ser atribuído ao boom mineral, que começou na década anterior (SELVANATHAN; SELVANATHAN, 1999). Neste período, houve o aumento das descobertas e da exploração de vários minérios, em particular, os destinados à transformação industrial, como alumínio, cobre, estanho, ferro, zinco e outros metais, setor que se encontrava aquecido no Pós-Guerra (GOVETT; GOVETT, 1982). O estímulo estava atrelado, majoritariamente, à demanda dos EUA, da Europa ocidental e do Japão, que recompunham suas economias internas. Em consequência, houve o redirecionamento do capital investido na mineração de ouro para outros depósitos minerais pelo mundo. Acrescentamos, sobretudo, que as fartas minas da África do Sul, maior exportadora de ouro do mundo, na época, começaram a ficar profundas e perder produtividade e que sanções comerciais foram aplicadas aos sul-africanos em represália à política de apartheid. Averiguamos, portanto, que o ímpeto de extração mundial não responde, de maneira instantânea, ao avanço do preço iniciado em 1971, tendo expressado alguma reação apenas a partir de 1981, o que se deve, possivelmente, a cautela das empresas por conta do novo padrão de instabilidade do preço instituído na década de 1970. 


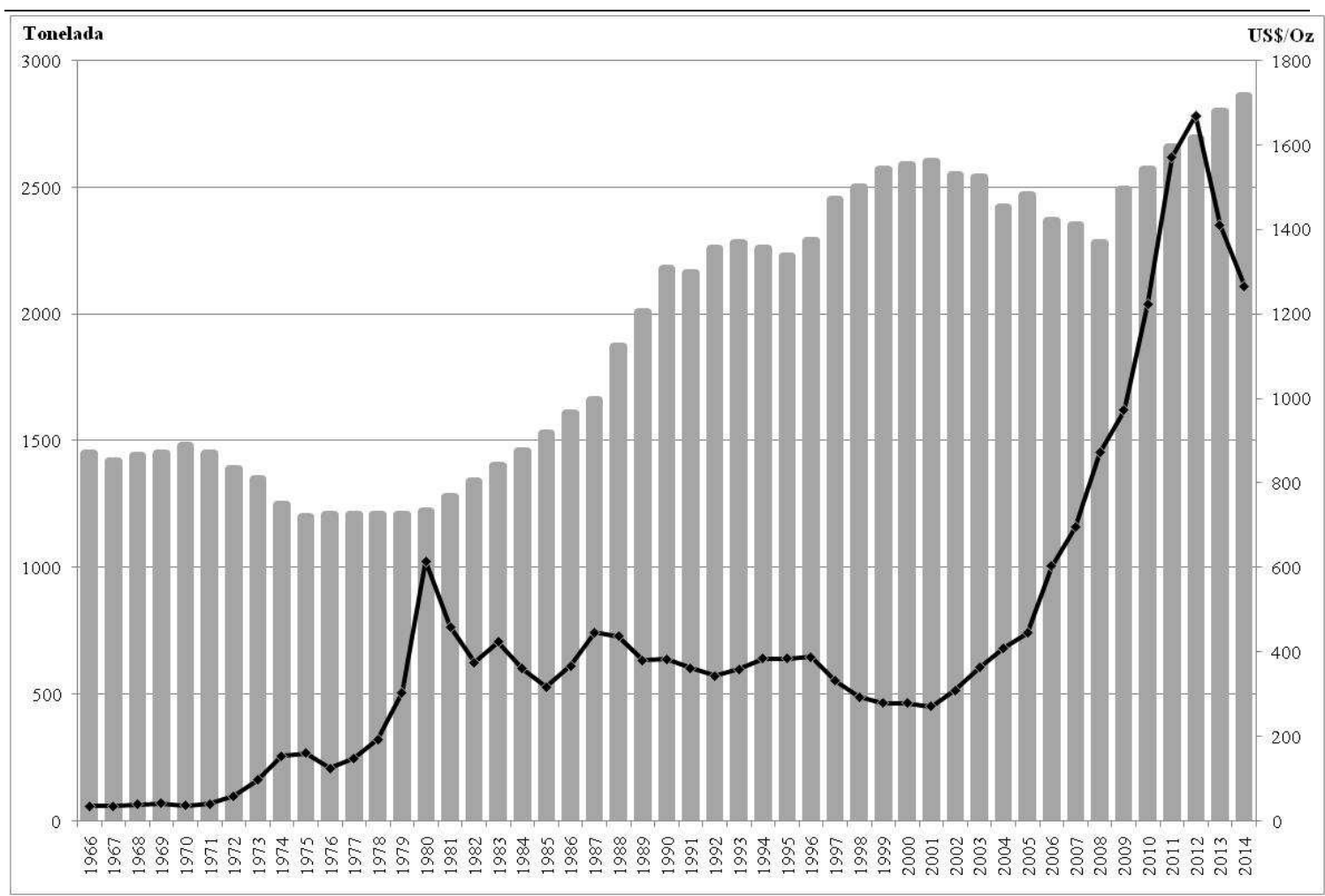

Figura 4: Evolução da Extração Mundial de Ouro e Preço Médio Anual (1966-2014)

Fonte: USGS (O dado referente a 2014 é estimado).

No começo da década de 1980, observamos o crescimento acelerado da extração mineral, que praticamente dobrou em uma década (passou de 1220 toneladas em 1980 para 2180 ton. em 1990). O aumento da exploração está relacionado, em parte, a definitiva transformação do ouro em commodity, com a instauração do câmbio flutuante e da livre cotação do metal no mercado financeiro internacional. A rápida valorização da commodity no fim dos anos 1970, que logo se estabilizou próxima aos 400 dólares/onça-troy por quase quinze anos, propiciou maior retorno financeiro às mineradoras e estimulou-as a investir em inovações tecnológicas e em novas minas. O mercado comprador também cresceu e se diversificou, incorporando progressivamente os investidores do mercado financeiro como principais consumidores do metal.

Ressaltamos que a mineração de ouro passou a vigorar, com alto grau de prioridade, nas agendas nacionais, recebendo suporte governamental (SHERVAL, 2009). Primeiramente, as empresas mineravam em locais de fácil extração, o que com o esgotamento das minas, obrigouas a investirem em inovações tecnológicas no processo de extração e na pesquisa geológica ${ }^{5}$. As mudanças tecnológicas incrementaram a produtividade e reduziram o custo operacional, permitindo inclusive a exploração de depósitos com menor teor de ouro contido (GREEN, 2007; SELVANATHAN; SELVANATHAN, 1999). No âmbito da regulação, novas medidas foram sendo implementadas no sentido de favorecer as grandes corporações, os grandes investimentos e as grandes minas. O período corresponde, portanto, a um marco na indústria da mineração de 
ouro, que mudou: da pequena mineração, artesanal e de baixa escala, para a grande mineração; de semi-intensiva em tecnologia, para intensiva em tecnologia; de individual e de pequenas empresas, para grandes corporações; de baixo investimento, para alto investimento; e de baixa relevância nacional, para grande relevância nacional (GREEN, 2007; BRIDGE; MCMANUS, 2000).

Na década de 1990, mesmo com a relativa estagnação do preço e até mesmo a depreciação do metal no final da década, se manteve a tendência de aumento da exploração até 2001, com apenas três leves reduções anuais. Nesta década, as políticas neoliberais e pautadas no desenvolvimento do setor extrativo mineral nos países e regiões periferias de recursos (HAYTER et al, 2003), potencializaram a internacionalização de grandes mineradoras transnacionais na América Latina, Ásia e África. Com a implementação de reformas e políticas neoliberais - a revisão dos códigos minerais, a desregulação das leis trabalhistas e ambientais, a política de privatizações, a garantia político-jurídica ao investimento externo, etc. - os riscos econômicos de investimento na periferia ficaram menores, enquanto os riscos em regiões mineradores tradicionais - como América do Norte e África do Sul - aumentaram, por conta do endurecimento das normas ambientais e sociais e do esgotamento das minas, no segundo caso (BRIDGE, 2004; EMEL; HUBER, 2008).

Neste processo houve a substituição parcial das pequenas minas, de extração mecanizada ou manual, por grandes minas nas regiões periféricas. Além disso, as principais minas nas regiões tradicionalmente mineradoras deram indícios de esgotamento. Assim, procurar novos depósitos em regiões remotas deixou de ser uma possibilidade, tornando-se necessidade (SHERVAL, 2009). Uma gama de novos países extratores surgiu dentre os tradicionais países mineradores nos anos de 1980, 1990 e 2000. Desde então, a mineração de ouro deixou, paulatinamente, de estar concentrada na África do Sul e na União Soviética (principalmente, na Rússia), se difundindo também por nações tradicionalmente extrativas como Canadá, EUA e Austrália e por países emergentes no setor mineral como China, Peru, Indonésia, dentre outros com volume de extração menor.

Com o preço do ouro extremamente baixo no final dos anos 1990 e a exaustão de muitos depósitos ao redor do mundo, a tendência foi de desaceleração do ímpeto da extração no princípio dos anos 2000. A última década do século também se caracterizou pelo endurecimento da regulação ambiental em diversos países, principalmente no mundo desenvolvido, o que significou o encarecimento do custo de extração e a diminuição da quantidade de minas, majoritariamente as de menor porte (DOGGETT; ZHANG, 2007). Frente ao panorama desanimador de baixo retorno financeiro, muitas minas fecharam e os investimentos em pesquisa mineral e em novas tecnologias diminuíram drasticamente. Por outro lado, há analistas, que defendem que existe uma diminuição das reservas mundiais de ouro como um todo, que não 
estão sendo repostas por novas descobertas (MILANEZ, 2012; WGC, 2011). Mesmo para a pequena mineração irregular e ilegal, o cenário foi de diminuição do ímpeto extrativo num contexto de maior repressão policial-estatal e baixo preço do metal.

A tendência decrescente seguiu de 2001 a 2008, quando o volume mundial extraído atingiu o patamar de 1.500 toneladas, inferior ao montante minerado uma década antes. No mesmo período, inicia o crescimento rápido do preço do ouro, em parte provocado pela diminuição da oferta, por outro, pela grande valorização das commodities em geral e a crescente demanda por joias nos países em desenvolvimento. Quando a exploração mundial atinge seu nível mais baixo, em 2008, o preço absoluto ultrapassava a máxima histórica de 850 dólares, de 1980. Somente a partir de então, o setor de mineração inverte a tendência de queda e começa a incrementar a oferta. Ou seja, assim como no primeiro ciclo de valorização do ouro, na década de 1970, a resposta do setor extrativo ao crescimento do preço tardou quase uma década. Mesmo considerando que o tempo estimado para a realização de um novo projeto mineral é de sete (7) anos, da fase de pesquisa ao início da extração (SHERVAL, 2009), o período de 10 anos para a reação do setor mineral à elevação do preço é bastante demorado. Principalmente, porque a expansão do potencial industrial de minas existentes ou desativadas requer bem menos tempo, e ainda diversas províncias geológicas já apresentavam pesquisas avançadas e levantamento de potencial mineralógico.

Após 2008, em consequência da supervalorização do metal ouro frente à crise monetária internacional, mas primordialmente pela tendência de aumento do preço das commodities em geral desde início da década, observamos o regresso da expansão da extração. O ímpeto da exploração manteve tendência crescente juntamente com o preço do metal. Aproveitando o excepcional momento de valorização, as grandes corporações transnacionais iniciaram novos projetos e expandiram empreendimentos antigos. As mineradoras juniors retomaram com força sua atuação no mercado de risco, em especial em áreas remotas. Assim, novas regiões do mundo assumem o protagonismo no mercado do ouro e outras aparecem como novas oportunidades para expansão da atividade mineral. Mesmo com a queda da cotação a partir de 2013, a tendência é que o movimento de crescimento e difusão da mineração aurífera no mundo prossiga firme por mais alguns anos, principalmente enquanto o preço se mantiver atrativo. Naquele ano, a mineração mundial de ouro obteve leve crescimento de 3\%, alcançando 2772 ton. Em 2014, o preço do metal oscilou próximo dos US\$1250/Oz, mesmo patamar que encerrou 2013, não sofrendo significativa desvalorização.

Neste início de século, a mineração do metal aurífero está amplamente difundida pelo mundo. No âmbito geral da mineração, a América Latina assumiu a liderança dos destinos de investimentos em mineração, no começo da década de 2010. No caso do ouro, em particular, a China se tornou a maior fornecedora mundial com 13,4\% do volume extraído em 2012. 
Austrália, EUA, Rússia, Peru, África do Sul, Canadá, México, Uzbequistão, Gana, Brasil, Indonésia, Papua Nova Guine, e Chile completam os catorze maiores países mineradores de ouro (ver figura 5). A pequena mineração aurífera segue representativa no cenário global, participando com 25\% do volume extraído mundialmente, em 2011 (ICMM, 2012).

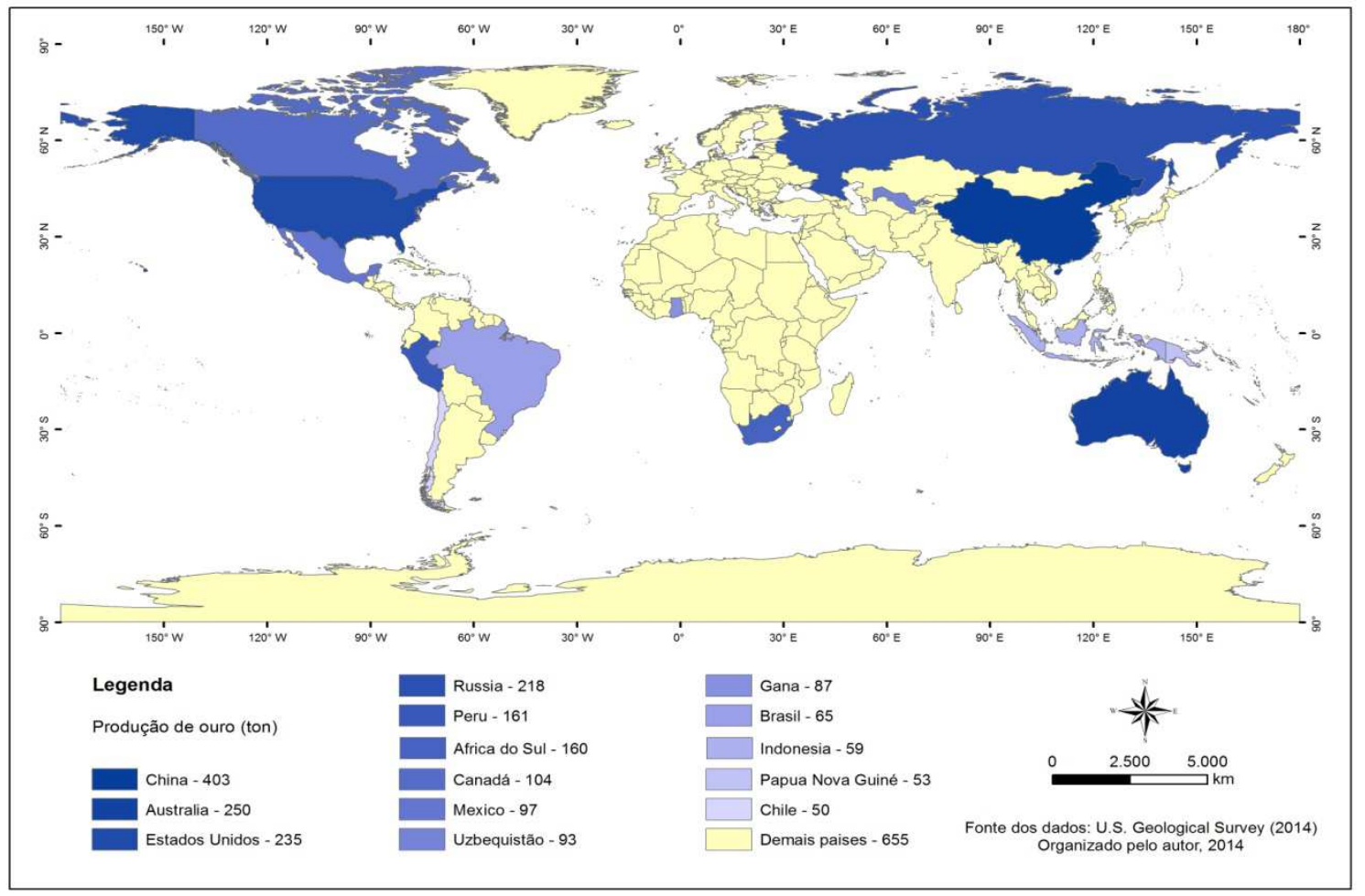

Figura 5: Principais Países Mineradores de Ouro no Mundo (2012)

Mesmo com a exploração difusa espacialmente pelo globo, o mercado ficou mais concentrado nas mãos de poucas grandes corporações transnacionais, que executam grandes projetos. O princípio do século XXI foi de importantes aquisições e fusões no setor mineral aurífero, consolidando um forte oligopólio no qual as 11 maiores mineradoras extraíram juntas, em 2012, 36,7\% (978,78 t) da exploração mundial (2.700 t), como se constata no Quadro 1. As corporações transnacionais são, principalmente, de origem canadense e sul-africana, dois tradicionais países mineradores de ouro. No entanto, elas encontram-se espalhadas espacialmente, minerando depósitos em diferentes regiões do globo.

A canadense Barrick Gold vigorava como a maior empresa do setor, concentrando 8,5\% do volume extraído, e com plantas industriais distribuídas por 11 países, nas Américas do Norte, Central e do Sul, na Oceania e na África. A única estadunidense listada entre as 11 maiores mineradoras, a Newmont Mining, a segunda colocada do ranking, com 5,7\% do volume extraído no mundo, opera em sete países das Américas do Norte e do Sul, da Oceania e da África. A terceira colocada dentre as maiores mineradoras de ouro, a sul-africana Anglogold Ashanti também possui projetos em 11 países, nas Américas do Norte, do Sul, na Oceania e na 
África. A Gold Fields, também da África do Sul, explora em cinco países, na América do Sul, África e Oceania. A canadense Kinross Gold atua em seis países, na Ásia, nas Américas do Sul e do Norte e na África. A conterrânea Goldcorp opera em oito países do continente Americano. A única australiana entre as maiores, a Newcrest Mining, encontra-se em cinco países, quatro na Oceania e um na África. As únicas que só possuem minas nos países-sede são a russa a Polyus Gold e a peruana Compania de Minas Buena Ventura. A sul-africana Harmony Gold Mining, além do país de origem, explora na Papua Nova Guiné, na Oceania. Já a Yamana Gold, a quarta canadense que compõe o ranking, minera em três países da América do Sul e um na América do Norte, e é a única que não detém minas no país-sede.

\begin{tabular}{c|l|l|c|c}
\hline Ranking & \multicolumn{1}{|c|}{ Companhias } & País Sede & $\begin{array}{c}\text { Extração } \\
\text { em } \\
\text { Tonelada }\end{array}$ & $\begin{array}{c}\text { Participação } \\
\text { na Extração } \\
\text { Mundial }\end{array}$ \\
\hline 1 & Barrick Gold Corp & Canadá & 230,79 & $8,5 \%$ \\
\hline 2 & Newmont Mining Corporation & EUA & 154,90 & $5,7 \%$ \\
\hline 3 & Anglo Gold Ashanti Limited & África do Sul & 129,39 & $4,8 \%$ \\
\hline 4 & Gold Fields Limited & África do Sul & 102,64 & $3,8 \%$ \\
\hline 5 & Kinross Gold Corporation & Canadá & 78,07 & $2,9 \%$ \\
\hline 6 & Goldcorp Inc & Canadá & 74,34 & $2,7 \%$ \\
\hline 7 & Newcrest Mining Limited & Austrália & 64,38 & $2,4 \%$ \\
\hline 8 & Polyus Gold International & Rússia & 52,25 & $1,9 \%$ \\
\hline 9 & Harmony Gold Mining Co & África do Sul & 37,95 & $1,4 \%$ \\
\hline 10 & Compania de Minas Buenaventura & Peru & 32,97 & $1,2 \%$ \\
\hline 11 & Yamana Gold & Canadá & 30,04 & $1,1 \%$ \\
\hline- & Oligopólio do Ouro & \multicolumn{1}{c}{-} & 987,72 & $36,6 \%$ \\
\hline Total & Todas & - & 2.700 & $100 \%$ \\
\hline
\end{tabular}

Quadro 1: Maiores Mineradores do Mundo por Extração (2012)

Fonte: Mining.com

A década de 2000 representou o retorno das pequenas e médias mineradoras ao mercado do ouro, especialmente promovendo pesquisas e desenvolvendo projetos de novas minas em regiões remotas, ou região de recursos ${ }^{6}$ (HAYTER et al, 2003; SHERVAL, 2009). A mineração aurífera não era, necessariamente, um fato novo para as regiões remotas. Muitas delas foram áreas de fronteira de recursos, que vivenciaram expressivas corridas por ouro no século passado, e ainda permanecem como regiões de fronteira para o capital mineral industrial, servindo como oportunidades para companhias juniors, assim como para as grandes transnacionais, que aproveitaram o cenário favorável (SHERVAL, 2009). Após se confirmarem a viabilidade das jazidas, as pequenas companhias adquirem em operações de captação no mercado financeiro capital para executar o projeto ou são fundidas em transações com mineradoras maiores.

As grandes corporações mineradoras se tornaram importantes players no mercado de commodities, pois atuam não só diretamente na pesquisa, na extração, na oferta do metal e na expansão da fronteira mineral, como operam em bolsas buscando favorecer seus interesses de acumulação e para viabilizar empreendimentos minerais. No entanto, incluem-se ainda nesta 
geoeconomia do ouro uma variedade de outros participantes ligados ao mercado financeiro e a economia mineral, como investidores, especuladores, bancos, indústria de joias, indústria de equipamentos eletrônicos, consumidores e as empresas junior e senior de mineração.

\section{CONSIDERAÇÕES FINAIS}

A geografia da mineração de ouro na atual fase da globalização financeira não pode se limitar estritamente as relações socioespaciais dentro da cadeia produtiva, extração-transportetransformação-consumo de ouro em forma de joias ou barra. Ou seja, à participação e processos relativos aos atores que compram e vendem o metal aurífero para fins industriais. O ouro por ser uma mercadoria de duplo valor, servindo como matéria prima para indústria joalheira e reserva de valor monetário no mercado financeiro e no varejo, está condicionado a outros fatores e múltiplos atores para além da cadeia produtiva de transformação. Trata-se, portanto, de dois destinos distintos para o mineral extraído: a transformação do ouro por meio da indústria joalheira ou o consumo em barras, moedas ou mesmo em estado bruto no mercado formal, virtual-financeiro e ilegal para fins monetário, particularmente de reserva de valor.

Em cada momento histórico, o destino final predominante do ouro extraído varia em intensidade, de acordo com as conjunturas da economia internacional e nacionais. Em período de economia estável e de crescimento econômico duradouro observou-se uma concentração do ouro para fins da indústria joalheira, inclusive com maior consumo das classes alta e média nos países em crescimento. Em períodos de crise, em especial as crises monetárias, o metal tendeu a fluir para o mercado financeiro, para fins de salvaguardar os investimentos frente à volatilidade das moedas nacionais.

O rearranjo da economia do ouro, a partir da década de 1970, levou o metal aurífero a deixar de ser uma mercadoria de exclusivo controle e valoração por parte dos Estados e das grandes potências mundiais. Desde então, o metal passou a oscilar de acordo com os arranjos geoeconômicos ligados ao mercado financeiro global e a economia mineral. O metal migrou, portanto, de uma perspectiva geopolítica e territorial, ligada as disputas das grandes potências hegemônicas por reservas monetárias, para o campo de disputas geoeconômicas de mercado, no qual o Estado é apenas mais um ator na geometria do poder.

Neste contexto geoeconômico, a geografia da mineração de ouro no mundo é moldada por processos instituídos tanto no âmbito da economia financeira globalizada, como nos espaços nacionais. Os governos dos Estados-nacionais ainda têm um papel de suma relevância na economia mineral, pois em muitos países, detém o controle sobre os recursos minerais no subsolo e pode vir a agir diretamente sobre a regulação do setor de mineração e sobre o mercado de compra e venda do metal. Por outro lado, os governos das grandes potências que, até hoje, compra, vendem e possuem vultosas reservas do metal para fins monetários nos Bancos 
Centrais, podendo intervir no preço internacional do ouro. Os governos dos países centrais são inclusive os principais parceiros das maiores corporações mineradoras e onde muitas delas e os centros de negócios minerais se sediam. Também os governos de países periféricos participam da produção do espaço da mineração de ouro, abrigando e incentivando em seus territórios grande parte da extração mineral, em especial os novos grandes projetos das mineradoras transnacionais. As ações estatais e posturas políticas, assim como, e não só as tendências nos preços nacionais e internacionais, afetam diretamente a mineração e sua distribuição ao redor do mundo.

As corporações mineradoras são outros atores centrais, tanto o oligopólio formado por grandes mineradoras, que cada vez mais concentra o processo de extração, os investimentos no setor mineral, a tecnologia extrativa e se restringe a um limitado número de empresas; como as juniors que atuam como desbravadoras de novas áreas de extração, e como oportunidade para agentes especulativos do mercado financeiro. As grandes instituições financeiras privadas, incluindo os cada vez mais expressivos fundos de pensões, e multilaterais também possuem influência na geoeconomia mineral aurífera, pois se tornaram junto com a indústria joalheira o principal mercado consumidor do metal e, por vezes, atuam direta ou indiretamente (via compra de ativos) investindo nas mineradoras e nos novos e possíveis empreendimentos. O sistema financeiro apresenta outros atores que atuam para maximizar seus lucros, operando contra e a favor da valorização da commodity.

Em suma, trata-se de dois campos de ação política e econômica que atuam concomitantes e, por vezes, inter-relacionados: a esfera do mercado financeiro em compras de ouro para fins monetários, mas também de operações, não materializadas no metal - contratos futuros, swaps, opções, hedging, etc - de cunho prático e especulativo; e a esfera da cadeia de commodities iniciada nas pesquisas minerais in situ, passando pela extração, transporte, transformação e consumo, cuja finalidade pode variar entre indústria joalheira e compradores de barras e moedas para fins monetários, em particular bancos.

$1 \quad$ O caráter de mineral estratégico atribuído ao ouro, que perdeu em parte sentido com o fim do tratado de Bretton Woods, mas por vezes pode ser retomado unilateralmente por alguns poucos Estados Nacionais, por conta das crises financeiras internacionais e a estratégia de elevar as reservas monetárias em ouro (Venezuela e Bolívia, por exemplo, durante a crise de 2008).

$2 \quad$ Segundo o trabalho de Walter Labys, Jean Lesound e Dominique Badillo (1998), entre 1985 e 1990, o ouro foi o metal - dentre alumínio, cobre, chumbo, estanho, ouro, prata, tungstênio e zinco - que obteve o menor grau de volatilidade. Na sequência, entre 1990 e 1995, o metal aurífero manteve uma volatilidade baixa, assim como os outros metais. O tungstênio, estanho e chumbo ficaram com índices inferiores ao ouro. Na média dos dez anos analisados o ouro foi o segundo metal com menor volatilidade, perdendo apenas para o tungstênio.

Mineradoras juniors são empresas de pequeno porte, em capital, patrimônio e valor de mercado, que atuam no mercado financeiro visando captar recursos para pesquisa mineral ou para construção de plantas de extração. Por se tratar de ações de alto risco, o retorno de investimentos nestas pode gerar elevados ganhos caso prosperem. 
$4 \quad$ Hedge são operações, por meio de contratos futuros com preços prefixados, realizadas por empresas e investidores visando se proteger dos riscos das oscilações de preços no mercado de compra e venda.

Dentre as mudanças tecnológicas destacam-se o desenvolvimento da Geofísica e da Geoquímica, que transformaram a prospecção e o desenvolvimento das minas com a incorporação da mina a céu aberto e o uso de cianeto (SHERVAL, 2009).

6 Em seu livro "The Geopolitics of Gold: Narratives of Globalization and Remote, Resource Economies" a australiana Meg Sherval (2009) trabalha com o conceito de regiões remotas. A autora as compreende como regiões periféricas de recursos que, na maioria das vezes, são espaços afastados das core areas, misteriosos, estigmatizados, caros para acessar, politicamente instáveis e algumas vezes perigosos. A noção de região remota é um complemento da noção de periferia de recursos. Noção que se refere ao espaço periférico da economia global fornecedor de commodities, energia e produtor de industrializados de baixa tecnologia ou que possuem recursos para tanto (HAYTER et al. 2003). 


\section{REFERÊNCIAS BIBLIOGRÁFICAS}

BAUR, Dirk. Explanatory mining for gold: contrasting evidence from simple and multiple regressions. Resources Policy, v. 36, 2011. p. 265-275.

; LUCEY, Brian. Is gold a hedge or a safe haven? An analysis of stocks, bonds, and gold. The Financial Review, v. 45, 2010. p. 217-229.

; MCDERMOTT, Thomas. Is Gold a Safe Haven? International Evidence. Journal of Banking and Finance, v. 34, 2010. p. 1886-1898.

BECKMANN, Joscha; CZUDAJ, Robert. Oil and gold price dynamics in a multivariate cointegration framework. International Economics and Economic Policy. v. 10, 2013. p. 453468.

BELLUZZO, Luiz. Finança Global e Ciclos de Expansão. In: FIORI, José Luis. (Org) Estados e moedas no desenvolvimento das nações. Petrópolis: Vozes, 1999. p 87-119.

BENKO, Georges. Economia espaço e globalização na aurora do século XXI. São Paulo: Ed. Hucitec, [2002] 1994.

Mundialização da economia, metropolização do mundo. Revista do Departamento de Geografia, v. 15, 2002. p. 45-54.

BRENNER, Neil. The limits to scale? Methodological reflections on scalar structuration. Progress in Human Geography. v. 25, n. 4, 2001. p. 591-614.

BRIDGE, Gavin. Mapping the bonanza: Geographies of mining investment in an era of neoliberal reform. The Professional Geographer. v. 56, n. 3, 2004. p. 406-421.

; MCMANUS, Phil. Sticks and stones: environmental narratives and discursive regulation in the forestry and mining sectors. Antipode, v. 32, n. 1, 2000. p. 10-47.

BUNKER, Stephen. Matter, space, energy, and political economy: the Amazon in the worldsystem. Journal of World-Systems Research, v. IX, n. 2, 2003. p. 219-258

CASTELLS, Manuel. Sociedade em rede. v. 1. Rio de Janeiro: Paz e Terra, [2000], 1996.

CHESNAIS, François. A Mundialização do capital. São Paulo - SP, Xamã, 1996.

CORPATAUX, José; CREVOISIER, Olivier; THEURILLAT, Thierry. The expansion of the finance industry and its impact on the economy: a territorial approach based on Swiss pension funds. Economic Geography, v. 85, n. 3, 2009. p.313-334.

CRAIG, James; RIMSTIDT, Donald. Gold production history of the United States. Ore Geology Reviews, v. 13, 1998. p. 407-464.

CULLEN, Ross; CRAW, David. Gold mining, gold prices and technological change. New Zealand Economic Papers, v. 24, 1999. p. 42-56. 
EGLER, Claudio. As vias abertas para América do Sul. In: BICALHO, Ana Maria; GOMES, Paulo Cesar (Org.). Questões de metodológicas e novas temáticas na pesquisa geográfica. Rio de Janeiro: Publit, 2009. p. 45-70.

Energia e conflitos territoriais na América do Sul: Uma visão geoeconômica. VII

Encontro Nacional da ANPEGE, Niterói - RJ, 2007.

EMEL, Jody; HUBER, Matthew. A risky business: Mining, rent and the neoliberalization of “risk”. Geoforum, n. 39, 2008. p. 1393-1407.

MAKENE, Madoshi. Extracting sovereignty: capital, territory and gold mining in

Tanzania. Political Geography, n. 30, 2011. p. 70 - 79.

FRENCH, Shaun; LEYSHON, Andre; WAINWRIGHT, Thomas. Financializing space, spacing financialization. Progress in Human Geography, 2011. p. 798-819.

FUKUYAMA, Francis, The middle-class revolution. International Policy Centre for Inclusive Growth Poverty Practice, Bureau for Development Policy, n. 26, UNDP, 2013. p. 8-9.

GOVETt, M; GOVetT, G. Gold demand and supply. Resources Policy. n. 8, v. 2, 1982. p. 84-96.

GREEN, Timothy. Central Bank gold reserves: an historical perspective since 1845. London, World Gold Council, 1999.

The ages of gold: mines, markets, merchants and goldsmiths. From Egypt to Troy, Rome to Byzantinum and Venice to the space age. London: GFMS, 2007.

HAESBAERT, Rogério. O mito da desterritorialização: Do "fim dos territórios" à multiterritorialidade. Rio de Janeiro - RJ: Bertrand Brasil, 2004.

HARVEY, David. A condição pós-moderna. São Paulo: Loyola, [1994], 1989.

Enigma do capital e as crises do Capitalismo. São Paulo-SP: Boitempo, 2010.

O Neoliberalismo: história e implicações. São Paulo: Ed. Loyola, 2003.

HAYTER, Roger; BARNES, Trevor; BRADSHAW, Michael. Relocating resource peripheries to the core of economic geography's theorizing: rationale and agenda. Area, v. 35, n. 1, 2003. p. $15-23$

HUGHES, Alex; REIMER, Suzanne (org.). Geographies of commodity chains. London and New York: Routlege, Studies in Human Geography, 2004.

ICMM - INTERNATIONAL COUNCIL ON MINING \& METAL. Mining's contribution to sustainable development, ICMM, 2012.

KRUGMAN, Paul. A Crise de 2008 e a Economia da Depressão. Rio de Janeiro: Elsevier/Campus, 2009.

LABYS, Walter; LESOUND, Jean; BADILLO, Dominique. The existence of metal price cycles. Resources Policy. v. 24, n. 3, 1998. p. 147-155. 
LE, Thai-Ha; CHANG, Youngho. Oil and gold: correlation or causation? DEPOCEN Working Paper Series, n. 22, 2011.

MARSTON, Sallie; JONES III, John Paul; WOODWARD, Keith. Human geography without scale. Transactions of the Institute of British Geographers, n. 30, 2005. p. 416-432.

MARX, Karl. Grundrisse: manuscritos econômicos de 1857-1858. Esboço da crítica da economia política. Rio de Janeiro - RJ: Boitempo/ Ed. UFRJ, [2011] 1858.

MASSEY, Dorren. Um sentido global do lugar In: ARANTES, Antônio Augusto (Org.) O espaço da diferença. Campinas - SP: Papirus Ed., 2000.

MILANEZ, Bruno. O novo marco legal da mineração: Contexto, mitos e riscos. In: MALERBA, Julianna (org.). Novo marco legal da mineração no Brasil: Para quê? Para quem? Rio de Janeiro: FASE, 2012. p. 19-90.

NATAL, Jorge Luiz. Mudanças recentes no capitalismo mundial e brasileiro: Alguns desdobramentos espaciais. In: NATAL, Jorge (org.) Território e planejamento: 40 anos de IPPUR/UFRJ. Rio de Janeiro - RJ: Letra Capital / IPPUR, 2011. p. 45-55.

O'BRIEN, Richard. Global financial integration: The end of Geography. London: Royal Institute of International Affairs, Pinter Publishers, 1992.

; KEITH, Alasdair. The geography of finance: After the storm. Journal of Regions, Economy and Society, 2, 2009. p. 245-265.

PAULINO, Robério. Desregulamentação, desindustrialização e reconcentração de renda na crise dos EUA. Revista de Economia Política e História Econômica, n. 31, 2014. p. 63-88.

PECK, Jamie; TICKELL, Adam. Neoliberalizing space. Antipode, v. 34, n. 3, 2002. p. 380405.

ROCKERBIE, Duane. Gold prices and gold production Evidence for South Africa. Resources Policy, 25, 1999. p. 69-76.

SELVANATHAN, Saroja; SELVANATHAN, E. A. The effect of the price of gold on its production: a time-series analysis. Resources Policy, 25, 1999. p. 265-275.

SERRANO, Franklin. Relações de poder e a política macroeconômica americana, de Bretton Woods ao padrão dólar flexível. In: Fiori, José Luís. O poder americano. Petrópolis: Vozes, [2007] 2004. p. 179-222.

SHAFIEE, Shahriar; TOPAL, Erkan An overview of global gold market and gold price forecasting. Resources Policy, 35, 2010. p. 178-189.

SHERVAL, Meg. The Geopolitics of Gold: Narratives of globalization and remote, resource economies. Saarbrücken, Alemanha: Verlag Dr Müller, 2009.

VALE, Eduardo; HERRMANN, Hildebrando. Economia mineral do ouro no Brasil. In: TRINDADE, Roberto; FILHO, Olavo. Economia mineral do ouro - Extração mineral: princípios, tecnologia e meio ambiente. CETEM/MCT, 2002. p. 297-312. 
VIRILIO, Paul. The information bomb. New York / London: Verso, 2000.

WGC - WORLD GOLD COUNCIL. The Evolving structure of gold demand and supply.

WGC, 2011.

YOUNG, John. Gold: At what price? The need for a public debate on the fate of National

Gold Reserves. Washington/USA: Mineral Policy Center, 2000.

ZHANG, Yue-Jun; WEI, Yi-Ming. The crude oil market and the gold market: Evidence for cointegration, causality and price discovery. Resources Policy, v. 35, 2010. p. 168-177. 